\title{
Open Government Partnership in São Paulo City and the São Paulo Aberta program: challenges in the diffusion and institutionalization of a global policy
}

\author{
GABRIELA DE BRELÀZ ${ }^{1}$ \\ TAMARA ILINSKY CRANTSCHANINOV ${ }^{2}$ \\ LAILA BELLIX ${ }^{3}$ \\ ${ }^{1}$ Universidade Federal de São Paulo (UNIFESP) / Escola Paulista de Política, Economia e Negócios, Osasco - SP, Brazil \\ ${ }^{2}$ Fundação Escola de Sociologia e Política de SÃo Paulo (FESPSP) / Programa de Pós-Graduação em CiênCIa Política, \\ SÃO PAULO - SP, BRAZIL \\ ${ }^{3}$ INSTItUto de Governo Aberto (IGA), SÃo PAUlo - SP, BRAZIL
}

\begin{abstract}
Brasil ha sido un lugar importante para implementar prácticas participativas después de su democratización. En 2011, junto con otros siete gobiernos fundadores, Brasil respaldó la Alianza para el de Gobierno Abierto (OGP) y anunció los planes del país para promover una mayor transparencia en las prácticas gubernamentales. El país se convirtió en parte de una iniciativa multilateral que hoy reúne a más de 70 países. Desde su difusión internacional, esta iniciativa fue incorporada por la ciudad de San Pablo, que creó el Comité Intersecretarial de Gobierno Abierto en 2014. Describimos la incorporación de la OGP y de su proceso de difusión y discutimos los desafíos de difusión e institucionalización de una política global a nivel local, entre 2013 y 2016. Las principales conclusiones abordan la importancia de institucionalizar las prácticas políticas además de la difusión de políticas; la importancia del análisis microinstitucional y del trabajo institucional en la teoría organizacional para comprender la importancia de los actores clave en el proceso de implementación; y la influencia de la arquitectura institucional en la implementación de la OGP.
\end{abstract}

Keywords: Open government. Diffusion. Public policy institutionalization.

Open Government Partnership na cidade de São Paulo e o programa São Paulo Aberta: desafios na difusão e institucionalização de uma política global

\section{Resumo}

O Brasil tem sido um importante locus de implementação de práticas participativas após sua democratização. Em 2011, ao lado de outros sete governos fundadores, o Brasil endossou a Open Government Partnership (OGP) e anunciou os planos para promover maior transparência nas práticas governamentais. O país passou a fazer parte de uma iniciativa multilateral que hoje reúne mais de 70 países. A partir de sua difusão internacional, essa iniciativa foi incorporada pela cidade de São Paulo, que criou o Comitê Intersecretarial de Governo Aberto em 2014. Descrevemos a incorporação do OGP a partir de seu processo de difusão e discutimos os desafios de difusão e institucionalização de uma política global no nível local, ocorrida entre 2013 e 2016. As principais conclusões abordam a importância da institucionalização das práticas políticas além da difusão de políticas; a importância da análise microinstitucional e do trabalho institucional na teoria organizacional para compreender a importância dos principais agentes no processo de implementação; e a influência da arquitetura institucional na implementação do OGP.

Palavras-chave: Governo aberto. Difusão. Institucionalização de políticas públicas.

Open Government Partnership en la ciudad de São Paulo y el programa São Paulo Abierta: desafíos en la difusión e institucionalización de una política global

\begin{abstract}
Resumen
Brasil ha sido un lugar importante para implementar prácticas participativas después de su democratización. En 2011, junto con otros siete gobiernos fundadores, Brasil respaldó la Alianza para el de Gobierno Abierto (OGP) y anunció los planes del país para promover una mayor transparencia en las prácticas gubernamentales. El país se convirtió en parte de una iniciativa multilateral que hoy reúne a más de 70 países. Desde su difusión internacional, esta iniciativa fue incorporada por la ciudad de San Pablo, que creó el Comité Intersecretarial de Gobierno Abierto en 2014. Describimos la incorporación de la OGP y de su proceso de difusión y discutimos los desafíos de difusión e institucionalización de una política global a nivel local, entre 2013 y 2016. Las principales conclusiones abordan la importancia de institucionalizar las prácticas políticas además de la difusión de políticas; la importancia del análisis microinstitucional y del trabajo institucional en la teoría organizacional para comprender la importancia de los actores clave en el proceso de implementación; y la influencia de la arquitectura institucional en la implementación de la OGP.
\end{abstract}

Palabras clave: Gobierno abierto. Difusión. Institucionalización de políticas públicas. 


\section{INTRODUCTION}

The practices of participation and transparency in public policies, despite being on the agenda since the process of re-democratization in Brazil, and especially since the 1988 Federal Constitution, were strengthened in the period after 2010. This occurred, among other factors, due to the diffusion and use of the internet by governments as a measure of both digitalization of services and administrative processes, and as forms of relationship and communication with the population. Added to this was the intense process of decentralization of power to the municipalities, also since 1988, which guaranteed them the possibility of innovating in the conduct of their public policies.

In this interface between participation, transparency, use of technologies and fighting corruption, the Open Government Partnership (OGP) emerged in 2011, a multilateral initiative between countries that seeks to (i) assume the agenda by signing the Open Government Declaration ${ }^{1}$; (ii) establish commitments in Action Plans and; (iii) establish independent evaluation processes.

In 2014, the City of São Paulo created its own open government initiative, becoming the only city in Brazil to join OGP. São Paulo thus presented itself as an interesting case to understand the decentralization of the open government agenda, understood here as the process of agenda internalization at the municipal level. Therefore, this article aims to describe the OGP diffusion in São Paulo, present the different moments of policy institutionalization and discuss the challenges of diffusion and institutionalization of a global policy at the local level.

Institutionalist theory can be defined by three major schools of thought: rational choice institutionalism, historical institutionalism and organizational theory or sociological institutionalism. Despite their own characteristics and differences, the different types of institutionalism are united by the common conviction that institutions, institutional arrangements and social processes matter (Immergut, 2006; Hall \& Taylor, 1996). To explain our case study, we use the approach from organizational institutional theory.

The analysis is based on available secondary public data, such as legislation and governmental reports, and from the personal experience of two of the authors, who were members of the City of São Paulo's bureaucracy between 2013 and 2016, which is also the time frame of this article. The documentary analysis was carried out in a systematic way using the documents generated, such as minutes of meetings, workshops, plans, and laws, which, along with others, were used to understand how the process was carried out.

The article is organized as follows: first, an introduction on the diffusion of open government globally; subsequently, a description of the implementation of the agenda locally by the City of São Paulo; in the third section, we present elements of Institutional Theory that contribute to build a timeline of this process. As a conclusion, we highlight key points to the development and maintenance of the open government agenda at São Paulo.

\section{THE GLOBAL AGENDA OF OPEN GOVERNMENT}

Open government, according to the OGP concept, can be understood as the use of information and communication technology to provide access to information and spaces of participation for citizens; to promote transparency of government actions; and, consequently, to prevent and fight out corruption, thus strengthening the integrity of governmental affairs.

On the agenda debate within the field of public management, Ramírez-Alujas (2011) presents a tendency for state reform to promote changes within the State and in its relationship with society (Ramírez-Alujas, 2011). In a complementary way, Cruz-Rubio (2015) reinforces that open government is a paradigm that provides a model of aggregative democracy and an accessible, transparent and receptive government (Cruz-Rubio, 2015, p. 131).

However, according to Hu and Robinson (2012), the definition of open government no longer has the clear definition it once had $^{2}$. The simple act of providing information to the public can be considered open government, but the kind of information and the means by which it is provided affect how open a government is. When analyzing President Obama's Open Government

${ }^{1}$ Retrieved from https://www.opengovpartnership.org/process/joining-ogp/open-government-declaration

${ }^{2}$ Further information on the concept of open government can be found at: https://forum.etalab.gouv.fr/t/what-is-the-concept-of-open-governmentan-approach-to-its-principles/2590 Also check: http://www.gigapp.org/ewp/index.php/GIGAPP-EWP/article/view/43 
Directive, the Open Government Declaration (2011, p. 181) and its commitment to provide high-value information in formats that the public can easily locate and comprehend, the authors state that these policies have "blurred the distinction between the technologies of open data and the politics of open government", reminding that one can exist without the other. This means that a government can be transparent even without new technology, and that it can also provide open data on "politically neutral topics" and still be unaccountable. In this sense, it is important to distinguish between technological and political openness.

\begin{abstract}
Also, the new breadth of the "open government" label creates a natural cognitive association between civic accountability and the internet, which may be for the best. Accountability policies that embrace the internet are often a great deal more effective than those that do not. (It might even make sense to say that if a government is not transparent through the internet, it is effectively not transparent at all). But this shift might also allow government officials to placate the public's appetite for accountability by providing less nourishing, politically low-impact substitutes (Hu \& Robinson, 2012, pp. 202-203).
\end{abstract}

To become a member of OGP, candidate countries must endorse a high-level Open Government Declaration (Open Government Partnership, 2011), present a country action plan developed from public consultation proceedings and commit to independent reporting on their progress going forward. Taking into account the multi-stakeholder collaboration, OGP is overseen by a steering committee that includes representatives of governments and civil society organizations.

The Open Government Partnership was formally initiated on September 20, 2011, when the eight founding governments (Brazil, Indonesia, Mexico, Norway, the Philippines, South Africa, the United Kingdom and the United States) endorsed the Open Government Declaration and announced their country action plans. Since 2011, OGP has welcomed the inclusion of additional governments to the Partnership.

In total, $78 \mathrm{OGP}^{3}$ participating countries and 20 subnational governments have made over 2,500 commitments to make their governments more open and accountable (Open Government Partnership, 2016).

According to OGP, its main objective in organizing and diffusing open government is to collaborate with transformations in a comprehensive amount of policy initiatives, stimulating the highest levels of political openness from simple changes to more complex reforms, ensuring that these changes are benefiting citizens of member countries.

Brazil had a prominent position in OGP development. Since its launch, in September 2011, the country co-chaired the initiative with the United States until September 2012. The first annual meeting of the Partnership with 52 members was held in Brazil, and the country was also part of the Subcommittee of the Steering Committee for Leadership and Governance (Subcomitê do Comitê Diretor de Liderança e Governança), which is responsible for the enactment of governance regulations related to the partnership. According to Brazilian President Dilma Rousseff's speech:

For Brazil, open government is based on three inseparable pillars: transparency that allows for accountability; social participation that ensures citizenship; and systematic monitoring of results of public policies that assure quality management. All this is done using technologies that allow for adequate information, facilitate access and management and enable a more effective fight against corruption (OGP Annual Meeting, 2012).

The Office of the Comptroller General (Controladoria Geral da União - CGU) was responsible for leading Brazil's inclusion in the Open Government Partnership, working with the public sector and civil society, as well as preparing Brazil's Action Plan. The Interministerial Committee for Open Government (Comitê Interministerial para Governo Aberto - CIGA), established by a Presidential Decree enacted on September 15, 2011, is responsible for implementing and reviewing all Action Plans. CIGA consists of 18 federal government ministries and is coordinated by the Executive Office of the President of Brazil (Casa Civil). It also possesses an executive group formed by members from seven ministries that is coordinated by $\mathrm{CGU}^{4}$.

At the municipal level, it was during Fernando Haddad's administration (Haddad was from the same political party as President Dilma Rousseff), that the policy began, with the enactment of Decree no. 54.794/2014. This decree established the São Paulo Aberta Program and the Intersecretariat Working Group on Open Government (Comitê Intersecretarial para o Governo Aberto also with CIGA as its acronym), a committee with members from 13 municipal secretariats and São Paulo's Information and

\footnotetext{
${ }^{3}$ To check all current OGP members, refer to: https://www.opengovpartnership.org/our-members/.

${ }^{4} \mathrm{CIGA}$ still exists and the decree $\mathrm{n}$ o 10.160/2019 institutes the Interministerial Open Government Committee.
} 
Communications Technology Public Company (Empresa Municipal de Tecnologia da Informação e Comunicação - PRODAM) to recommend legislation as well as promote open government initiatives. São Paulo Aberta (meaning Open São Paulo) was a policy initiative to promote open government that was based on four principles: technology, participation, transparency and integrity. The use of technology is aimed at improving the lives of citizens; participation was seen as a fundamental aspect of the making of governmental decisions; transparency is paramount to government actions; and integrity is a must to curb corruption (São Paulo Aberta, 2017). According to Municipal Decree no. 54.794/2014:

Article 1 - The open government initiative São Paulo Aberta aims to integrate and articulate public actions and policies aimed at:

I - increasing transparency and access to public information;

II - the improvement of societal participation;

III - the promotion of technological innovation;

$I V$ - the strengthening of public integrity, through the prevention and fight against corruption;

$V$ - improvement of public governance;

$\mathrm{VI}$ - improvement of the provision of public services and administrative efficiency.

Interestingly, even though the program was implemented before OGP had developed an agenda towards local governments, it amounted to an adhesion to the entirety of OGP principles, as we describe in the following section.

\section{OPEN GOVERNMENT INSTITUTIONALIZATION IN SÃO PAULO: NATIONAL AND INTERNATIONAL DIFFUSION OF THE AGENDA}

The institutionalization of the open government agenda in São Paulo can be understood as composed by four different moments: (1) the formation of the political agenda and acknowledgment of the topic; (2) the formulation and implementation of open government initiatives; (3) the international recognition and the relationship with the OGP; and, finally, (4) paradiplomacy as a strategy for guaranteeing continuity. In this section, we provide a detailed account of each moment, following the development of the initiative.

\section{FIRST MOMENT - FIRST APPROACHES TO THE OPEN GOVERNMENT AGENDA IN THE CITY OF SÃO PAULO}

Signs of the open government agenda could already be found throughout the government's directives ${ }^{5}$ and in the actions taken within the very first months of Mayor Fernando Haddad's administration (2013-2016). These signs included the creation of departments responsible for transparency and integrity policies and the promotion of participatory planning frameworks. The creation of a city level Comptroller General's Office (Controladoria Geral do Município - CGM), with the enactment of Law no. 15,764, was one important measure, as it established areas devoted to internal affairs, promotion of integrity and the coordination of transparency policy. Although there were participatory spaces in São Paulo city such as councils and public audiences, it created a new participatory body, the municipal participatory councils, which were district-level oversight bodies responsible for monitoring the policies implemented by the thirty-two regional subprefectures. They also monitored the policies of the numerous public consultations and hearings, which included the revision of the city's master plan (which amounted to ten thousand contributions) and the development of an online platform in which citizens could submit suggestions for the Plano de Metas (Goals's Plan), which received a total of 9,400 suggestions on territorial activities and more than 800 electronic messages ${ }^{6}$.

\footnotetext{
${ }^{5}$ Fernando Haddad's Government Plan. 2012. Retrieved from http://divulgacandcontas.tse.jus.br/dados/2012/1699/SP/71072/11/250000050277/proposta.pdf 6 “Programa de Metas da Cidade de São Paulo 2013-2016". Retrieved from https://www.prefeitura.sp.gov.br/cidade/secretarias/gestao/programa_de_metas/ index.php?p=149999
} 
These initiatives indicated a movement towards a participatory, transparent and innovative style of governing within the administration. However, these actions were not accompanied by coordination efforts around a common agenda for all parties. With a lack of general guidelines for departments, each one individually promoted its own initiatives.

In this environment, the concept of open government, which combined the principles of participation, transparency, innovation and integrity, began to gain strength within the upper management. This was especially noticeable during the final drafting of the Plano de Metas, and it occurred for both internal and external reasons. Among these reasons were the inclusion of a core directive within the Plano de Metas ${ }^{7}$ regarding decentralized, participatory and transparent management in which City Hall is committed to a series of goals and actions to promote transparency, participation and innovation in all different governmental bodies; the establishment of a specific goal (goal 116) for creating a Digital Cabinet to promote digital participation, transparency and innovation; the rapprochement between technical areas of the Mayor's Cabinet, the General Comptroller's Office and the Secretariat of Planning, Budget and Management in internal meetings, a juncture in which the term "open government" appeared as a resounding narrative for the innovations in participation, transparency, integrity and technology that were being implemented at the beginning of the administration and that were to be furthered in the following years; and an internal process led by the Mayor's Cabinet to map participatory structures of the city that would subsidize the debates on new forms of participation (participation 2.0) and the Municipal Social Participation Policy and System.

As a result of these processes, there was a shift within goal 116, which initially aimed for the creation of a Digital Cabinet for the implementation of the São Paulo Aberta initiative. In this sense, the initiative was planned to coordinate the activities of several departments in the matters of participation, transparency and innovation that were occurring separately; to foster the adoption of open government management practices in all departments; and - though not formally - to contribute to the development of the agenda of social participation, an important directive of all Workers' Party administrations, especially with digital participation instruments.

Finally, it is also worth highlighting some important landmarks for the structuring of the São Paulo Aberta initiative. These include: the successful development of initiatives of public diffusion of the concept of civil society, such as the first São Paulo Aberta meeting in October of 2013; the organization of the first Hackathon, which released data from the public transportation system to citizens; São Paulo's first official disclosure of the term "open government»; and the São Paulo Diálogo Aberto (Open Dialogue) project, which took place in the "subprefeituras" (regional administration bodies) and had the presence of members of the Participatory Councils. Also worth noting is the establishment of CIGA, the Intersecretarial Committee of Open Government, through the enactment of Municipal Decree no. 54.794 in 2014.

\section{SECOND MOMENT - STRUCTURING THE AGENDA: PARTNERSHIPS AND ACTIONS DEVELOPMENT}

After CIGA was structured and the first public event to publicize the open government agenda, the "Encontro São Paulo Aberta" (São Paulo Open Meeting), was held, the initiative reached a new level.

Given the complexity of the concept of open government and the difficulties regarding internal disclosure and assimilation of its proposals, it was necessary to give greater concreteness to the theme. Faced with these challenges, the administration set as the second objective the establishment of partnerships in order to structure the agenda, and furthered a number of concrete actions which took place during the second and third years of government.

In this sense, some actions were developed to disseminate the concept and approximate open government to the daily routine of public servants, counselors and the general population. Several government-sponsored workshops and seminars were held at this time, as the ones presented in Box 1 below.

${ }^{7}$ Available at 4 note link 
Box 1

Workshops and seminars held on OGP diffusion in São Paulo

\begin{tabular}{|c|l|}
\hline Name & \multicolumn{1}{c|}{ Description } \\
\hline $\begin{array}{c}\text { Governo Aberto no Mundo } \\
\text { (Open Government in the World) }\end{array}$ & $\begin{array}{l}\text { Workshop aimed at public servants to disseminate the concept } \\
\text { practices of open government within City Hall. }\end{array}$ \\
\hline $\begin{array}{c}\text { Ciclo de Treinamento em Governo Aberto } \\
\text { (Workshop cycles in Open Government) }\end{array}$ & $\begin{array}{l}\text { Set of lectures on open government principles with partner } \\
\text { universities, such as University of São Paulo, University of Campinas, } \\
\text { Federal University of ABC and Getulio Vargas Foundation. Classes } \\
\text { on the subject were open to the public. }\end{array}$ \\
\hline $\begin{array}{c}\text { Agentes do Governo Aberto Program } \\
\text { (Open Government Agents) }\end{array}$ & $\begin{array}{l}\text { Program that provided grants for civil society representatives that } \\
\text { submitted proposals to offer courses and workshops in subjects } \\
\text { and activities related to open government principles to the public. }\end{array}$ \\
\hline
\end{tabular}

Source: Elaborated by the authors.

In the first year, more than fifteen thousand people participated in this program. In addition, São Paulo Aberta created the Open Cabinet Program, a talk show streamed live which served as an accountability tool, as it invited upper- and middle-level bureaucrats to answer questions sent in by the public, and for these bureaucrats to be held accountable for the activities they were responsible for. ${ }^{8}$

In the area of technological innovation, PRODAM, the city-owned ICT Company, created the Innovation Lab - LabProdam whose objective was to develop software and technology-driven tools to support management and foster participation.

In the dimension of social participation, the administration established the Comitê Intersecretarial de Articulação Governamental da Política Municipal de Participação Social (enacted by Decree no. 55,325 in 2014), an intersecretarial committee which was responsible for elaborating the municipal social participation policy as well as the participation system. With the tools created by LabPRODAM in a joint effort with other open government initiatives, the secretariats could easily adopt participatory practices in their activities, specifically the "Minutas Participativas" (Participatory Drafts), for public consultation of bills and regulation proposals. In addition to the digital sphere, the Comptroller General Office intensified the agenda of "Cafés Hackers", informal and collaborative meetings aimed at debating the opening of government data and technological solutions.

Throughout this process, the Secretariat for International and Federative Relations (SMRIF), in its role as coordinator of CIGA, was at the forefront of most of these actions and, due to its own formal competencies, could liaise with international organizations and governments to publicize what had been done in São Paulo. In this sense, São Paulo's initiative was presented in different foreign and international forums, in events such as the international missions to visit the White House, Madrid and the meetings of the OGP (Mexico in 2015). This meant that, during the period of implementation, the government's policies on open government could be presented, developed and shared with other governments and international organizations, corroborating with the strategy of diffusion that was part of the agenda. In addition to the international positioning of its initiatives, the Secretariat liaised with other municipalities and governments, including the federal government, to promote the agenda.

In addition to its formal role, the Secretariat played a strategic role both within and outside government. Internally, as an office close to the mayor and the position of its high and middle-level bureaucrats, it has managed to move across departments in order to promote coordinated actions, such as the "Gabinete Aberto" (Open Cabinet) or the "Agentes do Governo Aberto" (Open Government Agents), which involved an additional three secretariats. In its relationship with civil society, the Secretariat managed to liaise with different social movements and civil society organizations, such as the "Fórum de Gestão Compartilhada" (Shared Management Forum) for the construction of the Action Plan on Open Government, which is presented in the following sections.

Regardless of the partnerships that were developed, the actions on open government were still located in this place. Although several initiatives were joint efforts with other offices and external actors, Open Government as a topic did not cross beyond the limits of SMRIF and CGM, and the matter was seen internally as a guideline for these secretariats.

\footnotetext{
${ }^{8}$ Actions Retrieved from "São Paulo Aberta" book: https://issuu.com/spaberta/docs/livro_sp_aberta
} 
However, it was during those years that the theme of open government had its highlight - despite the difficulties - and gained traction within and outside municipal government. In the following section, we describe the next phase of the processes initiated in 2014 and 2015.

\section{THIRD MOMENT - INTERNATIONAL RECOGNITION OF INITIATIVES AND SELECTION IN THE OGP}

In relation to open government initiatives, the last year of the administration of Fernando Haddad (2016) can be understood as one of international recognition. Given that most initiatives had already been implemented and the topic of open government was gaining strength within and outside government ${ }^{9}$, São Paulo started to play a prominent role both nationally and internationally. In this period, the Open Government Agents Program was acknowledged as a candidate experience for the 10 International Observatory of Participatory Democracy (OIDP) Distinction "Best practices in Citizen Participation"10. The initiative was presented at the OIDP Forum in Barcelona.

In addition to this recognition, the Program was selected as one of the 10 Organisation for Economic Co-operation and Development (OECD) "Edge of Government" practices on the "citizens as experts" axis. For this selection, an OECD team visited the City Hall and took part in workshops offered by the Open Government Agents. The case was presented at a forum promoted by OECD in Dubai in early 2017 as a best practice to break boundaries between government and citizens.

Another case was the "Smart Citizens, Smarter State" study promoted by Gov Lab, an innovation lab sponsored by New York University, which recognized the Agentes de Governo Aberto (Open Government Agents) initiative as a best practice for citizen empowerment and government oversight ${ }^{11}$. Interestingly, the study coordinator at Gov Lab at the time was Beth Noveck, who was part of Barack Obama's team during the creation of the OGP and further open government initiatives in the United States government. Beth Noveck plays an important role as an international advocate on open government agenda and regularly cites the case of São Paulo in her lectures ${ }^{12}$.

Finally, the main case of international recognition was the selection of São Paulo to be part of the OGP pilot program of sub-nationalities in 2016. Selected by 14 other subnational governments around the world, São Paulo was the Brazilian representative for the promotion of the open government agenda in the years prior to the choice. In return, São Paulo would prepare an Open Government Action Plan, listing actions to be implemented in the following year. In the context of an international partnership, to be described in the following section, it was the responsibility of São Paulo's City Hall to develop and implement the action plan.

\section{FOURTH MOMENT - POLITICAL TRANSITION AND PARADIPLOMACY}

The fourth moment of the São Paulo Aberta initiative is the period of transition between the Haddad and Doria administrations and the implementation of two Actions Plans signed with the OGP.

Despite the transition in senior management positions, part of the technical staff remained during this period, mainly permanent civil servants. However, the São Paulo Aberta initiative, now named Supervisão para Assuntos de Governo Aberto (Supervision for Open Government Affairs), had its original team reduced to less than half of its previous staff. This reflects a weakening of the open government agenda in terms of its administrative and financial capabilities for policy implementation, which might risk its continuity. Waisbich (2018) corroborates this view regarding a lack of political will from upper-level bureaucracy to

\footnotetext{
${ }^{9}$ It is worth mentioning the amount of people involved in these activities and its growing popularity over the years. Around 100 people participated in the first meeting in 2013 and the "Ciclo de Formação" (training cycle). At the 1st Brazilian Open Government Meeting in 2015 , more than 200 people were present. This number also grew at the 2nd Brazilian Open Government Meeting in 2016 for 250 people.

${ }^{10}$ Agents of Open Government experience, at "Observatório Internacional da Democracia Participativa". Retrieved from https://oidp.net/pt/experience. php?id=1116>

${ }^{11}$ GOVLAB. City of São Paulo: Agents of Open Government. 2016. Retrieved from http://www.thegovlab.org/static/files/smarterstate/saopaulo.pdf

12 "Beth Noveck: Exigindo um governo mais aberto" vídeo. Retrieved from https://www.youtube.com/watch?v=bLGTrz1Zolk\&t=136s
} 
maintain and expand the implementation of open government policy ${ }^{13}$. Despite this, open data and transparency-related actions were detailed in the new Plano de Metas (2017-2020) ${ }^{14}$.

A second issue worth mentioning was the reassignment of SMRIF's role ${ }^{15}$. As it had been given a new directive to focus only on diplomacy, which related to the fact that its Deputy Secretary was a career diplomat, its new internal agenda was coherent with the OGP agenda. For this reason, paradiplomacy was fundamental for the continuity of the São Paulo Aberta initiative and the implementation of the OGP Action Plan, as it managed to commit the administration to maintaining its policies regardless of the administrative, financial and personnel resources deployed for such purpose. The paradiplomacy served so that the City Hall could assume international commitments with the OGP Action Plan and continue the actions.

Table 1, below, stresses how the budget related to open government actions has drastically decreased with governmental shifts. It is important to highlight that the budget is proposed in the year prior to its enactment, which means that Haddad was responsible for the budget increase from 2016 to 2017, just as Doria was responsible for its decrease in 2018 and 2019. Bruno Covas was responsible for its increase in 2020. In addition, open government actions could take place with other departments' budgets, such as Culture, Citizenship and Human Rights. Therefore, there is a nebulous zone in this analysis, but it is important to consider the pragmatic institutionalization through the budget.

Table 1

Forecasting of resources established in the Annual Budget Law (LOA) with actions related to Open Government, in Brazilian reais, 2015 - 2020

\begin{tabular}{c|c|c|c|c|c|c}
\hline Year & 2015 & 2016 & 2017 & 2018 & 2019 & 2020 \\
\hline Mayor & Fernando Haddad & Fernando Haddad & João Doria & João Doria & Bruno Covas & Bruno Covas \\
\hline Forecast (in reais) & $330,000.00$ & $320,000.00$ & $490,000.00$ & $290,000.00$ & $115,000.00$ & $264,000.00$ \\
\hline $\begin{array}{c}\text { Variation to } \\
\text { previous year }\end{array}$ & N/A & $(-) 3 \%$ & $(+) 53 \%$ & $(-) 41 \%$ & $(-) 60 \%$ & $(+) 130 \%$ \\
\hline
\end{tabular}

Source: Elaborated by the authors based on São Paulo City Hall (2020).

The role played by civil society organizations, especially the ones that are associated with the Fórum de Gestão Compartilhada (Shared Management Forum), a participatory governance structure composed of members of civil society and government established in 2016, which was responsible with the development and monitoring of the Action Plan, was also essential. These organizations remained active and were instrumental during the period of transition by providing translation of the agenda and advocating for the importance of maintaining the relationship with OGP.

In 2019, there were significant changes in the conduct of the agenda within the Municipality of São Paulo. Under the management of Bruno Covas, deputy mayor of João Doria, Supervision for Open Government Affairs was transferred to the Municipal Government Secretariat - central management body - through Decree no. 58,596 of 2019. In the midst of these changes, in October of the same year, Supervision joined the Executive Secretariat for Management of Strategic Projects of the Municipal Government Secretariat (Decree No. 59.000 of 2019), which reinforces the strategic position taken back to the open government agenda.

A sign of this resumption was the continuity of open government actions, such as: elaboration and implementation of the 2 nd Action Plan (2019-2020); five editions of the Open Government Agents Program, started in 2016, assumed as a commitment in the 2017 Action Plan 1 and with continuity in the following years; co-organization of the Brazilian Open Government Meetings; and Open Dialogue projects, a dialogue initiative with the subprefectures.

\footnotetext{
13 “Los retos que emergen frente a un proceso electoral: ¿Qué nos enseña el caso de Sao Paulo, Brasil?” Retrieved from https://www.opengovpartnership.org/ stories/los-retos-que-emergen-frente-un-proceso-electoral-qu-nos-ense-el-caso-de-sao-paulo-brasil

${ }^{14}$ São Paulo Goals Program. Retrieved from http://programademetas.prefeitura.sp.gov.br/

15 In João Doria's administration, the Secretariat of International and Federative Relations (SMIRF) went through administrative reform and was renamed Secretariat of International Relations (SMRI).
} 


\section{POLICY DIFFUSION AND THE INSTITUTIONALIZATION PROCESS}

The case of the São Paulo Aberta initiative and its relationship with the Open Government Partnership is an interesting case to analyze the relationship between paradiplomacy and the dynamics of local politics. São Paulo is the largest city in South America, with around 11 million inhabitants, reaching 20 million if one considers the greater metropolitan area around the city. It is an important economic and financial center and it accounts for around $11 \%$ of the Brazilian Gross Domestic Product - GDP.

Scholars from different areas have recently begun to address the issue of policy diffusion across countries in their research agendas, as the phenomenon became more frequent. According to Dobbin, Simmons and Garrett (2007), four different theories attempt to provide explanation and describe the mechanisms of policy diffusion: social construction, coercion, competition and learning.

When analyzing São Paulo Aberta, it is important to stress that it is an ongoing policy initiative that has changed due to changes in government (Fernando Haddad [2013-2016], João Doria [2017-2018] and Bruno Covas [2019-2020]), affecting the process of diffusion and the institutionalization of open government policy as stated here. Nevertheless, analyzing this ongoing process remains particularly interesting for both the study of policy diffusion as well as for the linkage between literature on policy diffusion and institutionalization process.

Constructionist theorists on policy diffusion use the lenses of social construction based on the seminal work of theorists such as Berger and Luckmann (1985), and Meyer and Rowan (1977), among others. On the matter of policy choices, Dobbin et al. (2007, p. 451) state that "both legitimate ends and appropriate means are shared social constructs that vary from one period to the next", and the same occurs with conventions among nation states: "Policy choices are based on fads, revered exemplars, or abstract theories, rather than solid evidence". Research demonstrates empirically how this process of social construction performed in the field of education and human rights policies. Could that also be the case in open government policies? Is it possible to observe a social construction in open government ideals?

Why countries adopt policies is a question that constructivists intend to answer. Social acceptance occurs when countries that lead initiatives serve as examples, when experts support new policy and recommend its adoption and when experts approve it under determined circumstances (DOBBIN et al., 2007). Brazil followed the United States OGP leadership and isomorphically became a co-leader in the process (DiMaggio \& Powell, 1991). As explained before, the OGP gained force as part of the Obama administration's efforts to promote government accountability.

Coercion is also relevant to policy diffusion, and it happens when governments or multilateral agencies, for example, guarantee the adoption of policy either by physical force (hard power), trade agreements that establish it as a requirement, or even exercising information or expertise monopoly (soft power). Competition theorists believe that policy diffusion occurs when "countries compete for capital and export markets. Governments have little choice but to choose market-friendly policies to attract global investment and keep exports competitive" (p. 457). In addition, the last theoretical framework used to analyze policy diffusion, learning, "occurs when new evidence changes our beliefs" ( $p .460)$, meaning that changes in policy occur when ideas and beliefs change.

In the case of São Paulo Aberta, we are not concerned with the issue of diffusion of the open government ideals through the OGP agreement, but with the issue of weakening or even the discontinuity of an important policy in a democratic state. We address these concerns in the following sections by discussing participatory practices and institutionalization. This article will stress institutionalization in organizational theory. As this field is broad and with different currents of thought, we will focus on what Grigoletto and Alves (2019) call the third wave of institutional theory that is focused on its microfoundations. These authors contribute to this field by presenting a classification of three waves of institutional studies, since its beginning with the seminal work of Philip Selznick (1949). 


\section{An institutional approach to civil society and participation}

Institutionalization is a process by which social behaviors, obligations or realities assume the status of rule in social thinking and in action (Meyer \& Rowan, 1977). It becomes clear that time is directly linked to institutionalization, because institutionalization increases with the continuity of the transmission of procedures, routines, language and the training of players involved. The greater the institutionalization of an act, the greater capacity an institution has of maintaining it without societal control. On the contrary, with little institutionalization, direct societal control is necessary (Zucker, 1977). In contrast, in any attempt to change the process of internalization, a strong cultural persistence is inevitable. After the institutionalization process, there is a process of legitimization, when the objectification of an institutional order is transmitted to a new generation. In the final legitimization of an institutional order that connects past, present and future events, language plays a crucial role.

The institutional approach to organizations states that institutions are the result of human activity, but not necessarily the product of conscious design (DiMaggio \& Powell, 1991). The institutional approach to organizations lays emphasis on cultural and cognitive explanations that are highly useful for understanding the phenomenon of participation.

Combining the institutional concepts of Greenwood, Oliver, Sahlin and Suddaby (2008) and Scott (2008), we state that institutions are repetitive social behaviors seen as being right, sustained by regulatory, normative and cultural-cognitive elements which provide meaning to social exchange and enable the self-reproduction of the social order.

Within the range of the institutional approach to organizations, the micro-foundations of institutionalism (Powell \& Colyvas, 2008; Powell \& Rerup, 2017) and institutional work (Hamel, Lawrence \& Tracey, 2017; Lawrence, Sudabby \& Leca, 2011) are of prime importance to the analysis of the São Paulo Aberta program. These approaches highlight the importance of the individual (player) to the institutional analysis, re-examining the relationship between agency and institutions. Individuals are engaged in processes of institutional creation, maintenance, rupture and change, and their motivations, behaviors and relationships must be observed. Powell and Rerup (2017) "stress that most micro activities are daily mundane, aimed at sensemaking, alignment and muddling through. As groups of people engage in such actions and resist others' attempts as well, they may well transform practices and theories and alter personal identities" (p. 312) and affirm that studies on micro-foundations in the last decade have progressed significantly by developing theoretical arguments on how macro-level events are affected by micro-level activities. These individuals maintain and transform daily practices in which interests, values and passions overlap. In this type of analysis, special emphasis is given to the language, vocabulary and archives of an organization that provide a "Iongitudinal conversation" on how its activities are understood.

\section{The microfoundations of institutionalism}

As a new phenomenon, it is important to analyze São Paulo Aberta through the lens of what Powell and Colyvas (2008) and Powell and Rerup (2017) call "micro-foundations of institutionalism" and Lawrence et al. (2011) and Hampel, Lawrence and Tracey (2017) call "institutional work". The authors emphasize the need to develop institutional biographies; that is, analysis of the relation between specific individuals and institutions and the role of individuals and groups in creating, shaping and disrupting institutions. This means trying to answer three questions: what, who and how actors do institutional work.

Hwang and Colyvas (2011) point out that it is possible to develop a microanalysis of institutionalization that takes into account how institutions are formed by individuals in concrete social situations of day-to-day practice, and how they are subsequently sustained, altered or extinguished. This microanalysis serves as a subsidy for analysis of macro events and relationships. It is essential to have a richer understanding of how individuals situate themselves within social relations and to interpret that context; that is, how these individuals maintain and transform the institutional forces that guide daily practices, taking into consideration that interests and passions are involved in human behavior.

For the authors, institutional transformations tend to be subtle and require a certain period of time, rather than happening abruptly. Most micromotives are mundane and are being interpreted and shaped by institutional actors, transforming logics and changing identities. Thus, the authors emphasize that institutional analysis should pay more attention to the events of everyday life than to those deemed more specific and important; to less powerful members of organizations, not just their leaders; and to cultural and cognitive aspects, and not just political ones. In this context, special attention to rituals of interaction, to the mediating role of language and other categories will serve to clarify how routines and organizational rules are developed, became institutionalized and are subsequently abandoned. 
In terms of research methods, in order to understand how micro-impacts affect the emergence and continuity of institutions, attention must be given to language and vocabulary, as these are:

\begin{abstract}
[...] the protocols people use to engage in dialogue and achieve mutual understanding and intersubjective awareness. The next step is to see which aspects of language become codified into formal measures of performance and achievement. These constructed definitions become metrics by which people evaluate each other. As these performance or activity calculations occur, they become reified, that is, received and accepted as normal by their participants and adopted and imitated by others who were not part of their initial creation. In this way, local measures become "natural". Once natural, they become public, redefine and reinterpret history, evolve into models to which others aspire and are recognized as guides to achievement (Powell \& Colyvas, 2008, p. 292).
\end{abstract}

\title{
Institutionalization process
}

For DiMaggio and Powell (1991), in the sociological tradition, institutionalization is a process where certain social relations and actions are taken for granted. The concept of institutionalization and institutionalized was defined by Meyer and Rowan in the seminal work of 1977 as shown by Greenwood et al. (2008):

Institutionalization is the process by which "social processes, obligations or realities come to assume a rule like status in social thought and action" (Meyer \& Rowan, 1977, p. 341). Something is "institutionalized" when it has that rule-like status. In a famous turn of phrase, Zucker concluded that institutionalization means that "alternatives may be literally unthinkable" (1983, p.5). Tolbert and Zucker (1983) have suggested three indicators of institutionalized practices: they are widely followed, without debate, and exhibit permanence (Greenwood et al., 2008, p. 5).

Meyer and Rowan (1977) emphasize how the incorporation of procedures and structures of the institutional environment give legitimacy to the organization, and DiMaggio and Powell (1983) added that once a certain social fact has become institutionalized, action models that create unified answers to the uncertainty lead to institutional isomorphism; that is, the adoption of the same practices by several organizations that are looking to increase their legitimacy, since organizations that are deemed legitimate have their chances of survival increased.

The process of continuity, maintenance of transmission of actions, habits and procedures also increases institutionalization: "the more the history of the transmission process is known, the greater the degree of continuity that the actors assume" (Zucker, 1991, p. 87). Additionally, regarding the resistance to change within the analysis of cultural persistence, the author states that acts that are strongly institutionalized will resist attempts to change made by personal influence.

Lawrence, Winn and Jennings (2001) propose an analysis that emphasizes the temporal dynamics and mechanisms of power through the systematization of times and processes of institutionalization. They state that step and stability, two temporal dimensions of the process of institutionalization, depend on four mechanisms mobilized by agents to support the process of institutionalization: influence, strength, discipline and domination. Their contribution can be summarized as follows: presenting an understanding of the relationship between the step of the institutionalization process and the stability of the institutions produced, emphasizing the role of time in institutional theory; creating a new typology for the mechanisms that sustain the development and maintenance of institutions; critiquing the prevailing traditional model of institutionalization; and proposing new curves of institutionalization. In a traditional institutionalization curve there is an initial stage of acceptance, where innovation is first recognized and welcomed by few actors, then widely diffused and accepted within the field, and finally this phase is followed by saturation and complete legitimation. Finally, deinstitutionalization occurs, a concept that is not addressed in this study.

By presenting four mechanisms that influence the process of institutionalization, the authors demonstrate that there are different temporal variables shaping different possible processes. The first time variable considers that the degree of diffusion of a rule, practice, or technology within an organizational field can vary greatly (certain innovations spread quickly, others slowly), and this defines the step of institutionalization. The second time variable relates to the moment when an institution has reached the stage of legitimation and its practices are widely disseminated to all individuals. It concerns the stability of that institution; that is, how stable, permanent and influential the institution will be, whether it has been rapidly or gradually 
institutionalized. In relation to mechanisms of power, influence is a central form of power in organizations, but the processes of institutionalization are also influenced by mechanisms of force, discipline, and domination that, associated with episodic or systemic forms of power, will affect certain features related to processes of institutionalization. Systemic forms of power are more likely to provide stable and long-lived institutions than episodic forms of power. In the case of influence and discipline, the target of the power of both has agency capacity, that is, is able to choose. These mechanisms of power have influence on the temporal issue that involves the process of institutionalization.

\section{SÃO PAULO ABERTA: PAST AND PRESENT}

As mentioned in the first section, Fernando Haddad's administration created the São Paulo Aberta initiative and CIGA to recommend regulation and promote open government initiatives across all departments of government, aiming to increase transparency and the degree of access to public information; promote technology innovation; curb corruption; increase public governance; and improve the provision of public services, administrative efficiency and social participation.

This move towards internationalization by the local government of São Paulo expresses a current trend in local governments, as stated by Stern and Friendly (2017). Internationalization and networks are motivated by "push factors such as local problems and pressures; 2) pull factors such as opportunities and incentives (Marks, Nielsen, Ray \& Salk, 1994); and 3) facilitating factors such as personal resources, political style and culture, and institutional features (Baldershein, Buček \& Swianiewicz, 1999; Stren \& Friendly, 2017, p. 11).

The initiative was and still is conducted by the International Relations Secretariat of São Paulo and was conceived as the first municipal experience of OGP. For that reason, members of the Secretariat partook in several meetings with the Brazilian Office of the Comptroller General (Controladoria Geral da União - CGU) as well as in international missions. However, different from the regular procedures countries pursue to join OGP countries, São Paulo partook in a competitive selection process, having to comply with a number of requirements in order to become a candidate and eventually was accepted at OGP along with $15^{[14]}$ other local government bodies (Candido, 2017). São Paulo Aberta was already implementing an open government agenda in convergence with OGP principles, and this contributed to the acceptance of São Paulo in the OGP. Mayor Fernando Haddad, in an official letter to the OGP, said:

The city council concentrated its efforts on the structuring of initiatives that could give concrete form to the open government agenda in municipalities and, in this way, establish a clear and direct connection between the concepts that forge this international agenda with the local needs of the citizens of a global city as São Paulo. In this way, we elaborate, implement, monitor and evaluate a set of actions and programs directly linked to each of the four axes of the Open Government (Haddad, 2016).

In 2017, a new government was elected in São Paulo. João Doria, a newcomer from Partido da Social Democracia Brasileira PSDB (Brazilian Social Democracy Party), won the election in the first round with a campaign focused on delivering a better administration, which stated that he, a businessman who was not a politician, could deliver. In this sense, the terms efficiency, efficacy and effectiveness would mark his administration, which also would eradicate corruption. Due to budget reductions, caused by the economic and fiscal crisis Brazil was facing, along with the rearrangement of the municipal agenda, São Paulo Aberta staff were mostly dismissed. The team was reduced from twenty to four people, but the initiative was kept within the attributions of the International Relations Secretariat. Internationalization still was a priority of Doria's government, but it is currently directed to the development of Public Private Partnerships. Even though São Paulo Aberta is a member of OGP, the open government agenda does not exist as a priority anymore, as the replacement of São Paulo's Comptroller General was followed by an administrative reform that stripped the agency of its oversight capabilities.

João Doria left the City Hall to run for governor of the state of São Paulo, winning this election in 2017. In his place, his deputy, Bruno Covas, took over part of the open government actions, under new perspectives and with changes in its format, as stressed earlier in this text. Although they were partially suppressed in the Doria administration, it is not possible to say that they would be able to resurface, albeit under a new guise, in the Covas government. This is, perhaps, where the most 
interesting way of analyzing the institutionalization of the open government agenda in São Paulo is present: its reconfiguration and permanence even with the election of a political project that did not prioritize this agenda. Nevertheless, the changes of mayor and public servants responsible for the open government agenda directly affected the implementation of the policy and its institutionalization because people matter and are responsible daily for activities. The process of continuity, maintenance of transmission of actions, habits and procedures are essential to increase institutionalization.

\section{FINAL CONSIDERATIONS}

After analyzing the challenges in the diffusion and institutionalization of OGP in São Paulo, this article stresses three points. Firstly, the importance of institutionalization of policy practices beyond policy diffusion. That means that policy diffusion has limitations if these policies are not de facto institutionalized. Secondly, the importance of micro institutional analysis and institutional work to understand the importance of key agents in the implementation of a policy. When such actors are made absent, projects can be steered out of priorities or even be discontinued. If institutions matter, people also matter. Strategic people in strategic places make the difference. Thirdly, the influence of institutional architecture of the OGP implementation. The decision of hosting this policy under SMRIF, the Secretariat for International Relations, in Haddad's administration, is related to the staff that was involved in the process and that was a strong advocate for the open government agenda. When this staff is replaced, different governance structures might better suit the policy, as it is possible to observe in Bruno Covas' administration. As open government should be a comprehensive practice throughout the government, the coordination of OGP practices at the municipality would best be held by the Secretary of Government, which has the role of establishing the governance structure and the relationship between different secretariats within the administration. Finally, this research would greatly benefit from the perspective of policy discontinuity and how changes in government affect policy diffusion and institutionalization. In addition, further research on the transformation of the agenda under the Doria and Covas administrations would support the understanding of later phenomena. 


\section{REFERENCES}

Baldersheim, H., Buček, J., \& Swianiewicz, P. (2002). Mayors Learning across Borders: The International Networks of Municipalities in EastCentral Europe. Regional \& Federal Studies, 12(1), 126-137.

Berger, P., \& Luckmann, T. (1985). A construção social da realidade. Petrópolis, RJ: Vozes.

Cândido, C T. (2017). São Paulo Aberta: Uma análise do programa de Governo Aberto do município de São Paulo. In Anais do 25 Congresso de Iniciação Científica da UNIFESP, São Paulo, SP.

Cruz-Rubio, C. N. (2015). O que é (e o que não é) governo aberto? Uma discussão conceitual. Rev. Temas de Administração Pública, 10(1), 129-148. Retrieved from https://periodicos.fclar.unesp.br/ temasadm/article/viewFile/8583/6471

DiMaggio, P. J., \& Powell, W. W. (1983). The iron cage revisited: institutional isomorphism and collective rationality in organizational fields. American Sociological Review, 48(2), 147-160.

DiMaggio, P. J., \& Powell, W. W. (1991). Introduction. In P. J. DiMaggio, \& W. W. Powell (Eds.), The new institutionalism in organizational analysis (pp. 1-38). Chicago, IL: The University of Chicago Press.

Dobbin, F., Simmons, B., \& Garrett, G. (2007). The Global Diffusion of Public Policies: Social Construction, Coercion, Competition, or Learning? Annual Review of Sociology, 33, 449-472.

Greenwood, R., Oliver, C., Sahlin, K., \& Suddaby, R. (2008). Introduction. In R. Greenwood, C. Oliver, K. Sahlin, \& R. Suddaby (Eds.), The Sage handbook of organizational institutionalism (pp. 1-46). London, UK: Sage Publications.

Grigoletto, F., \& Alves, M. A. (2019). Leitura do institucionalismo organizacional a partir da teoria do organizar de Karl Weick. Cadernos EBAPE.BR, 17(2), 247-262.

Haddad, F. (2016). Ofício enviado a Senhora Kitty von Bertele, do Comitê Diretor da Open Government Partnership (OGP) - Parceria para Governo Aberto. São Paulo, SP: Prefeitura de São Paulo.

Hall, P. A., \& Taylor, R. C. R. (1996). Political science and the three new institutionalisms. Political Studies, 44(5), 936-957.

Hampel, C. E., Lawrence, T. B., \& Tracey, P. (2017). Institutional Work: Taking Stock and Making it Matter. In R. Greenwood, C. Oliver, K. Sahlin, \& R. Suddaby (Eds.), The Sage Handbook of Organizational Institutionalism (pp. 558-590). London, UK: Sage.

Hu, H., \& Robinson, D. G. (2012). The New Ambiguity of “Open Government". UCLA Law Review Discourse, 59, 178-208.

Hwang, H., \& Colyvas, J. A. (2011). Problematizing actors and institutions in institutional work. Journal of Management Inquiry, 20(1), 62-66.

Immergut, E. (2006). O núcleo teórico do novo institucionalismo. In E. Saravia, \& E. Ferrarezi (Eds.), Políticas públicas: coletânea (Vol. 1). Brasília, DF: ENAP.

Lawrence, T., Sudabby, R., \& Leca, B. (2011). Institutional work: refocusing institutional studies of organizations. Journal of Management Inquiry, 20(1), 52-58.

Lawrence, T. B., Winn, M. I., \& Jennings, P. D. (2001). The temporal dynamics of institutionalization. Academy of Management Review, 26(4), 624-644.
Marks, G., Nielsen, F., Ray, L., \& Salk, J. E. (1994). Competencies, Cracks, and Conflicts: Regional Mobilization in the European Union. Comparative Political Studies, 29(2), 164-192.

Meyer, J. W., \& Rowan, B. (1977). Institutionalized organization: formal structure as myth and ceremony. American Journal of Sociology, 83(2), 440-463.

Open Government Partnership. (2001). From commitment to action. Retrieved from https://www.opengovpartnership.org/wp-content/ uploads/2001/01/OGP_actionplan_guide\%20FINAL.pdf

Open Government Partnership. (2011, September). Open government declaration. Retrieved from https://www.opengovpartnership.org/ process/joining-ogp/open-government-declaration/

Open Government Partnership. (2016). Subnational Government Pilot Program. Retrieved from https://www.opengovpartnership. org/how-it-works/subnational-government-pilot-program

Open Government Partnership. (2018). São Paulo, Brazil - OGP Subnational Pioneers. Retrieved from https://www.opengovpartnership. org/how-it-works/subnational-government-pilot-program

Open Government Partnership. (2020a). Subnational São Paulo Plan. Retrieved from http://www.opengovpartnership.org/ subnational-saopaulo-plan

Open Government Partnership. (2020b). The Basic Engagement. Retrieved from https://www.opengovpartnership.org/how-it-works/ civil-society-engagement/engaging-civil-society-why-and-how

Open Government Partnership. (2020c). What is the Open Government Partnership? Retrieved from http://www.ogpireland. ie/what-does-open-government-mean/

Powell, W. W., \& Colyvas, J. A. (2008). Microfoundations of institutional theory. In R. Greenwood, C. Oliver, K. Sahlin, \& R. Suddaby (Eds.), The Sage Handbook of Organizational Institutionalism (pp. 276-298). London, UK: Sage.

Powell, W. W., \& Rerup, C. (2017). Opening the Black Box: The Microfoundations of Institutions. In R. Greenwood, C. Oliver, K. Sahlin, \& R. Suddaby (Eds.), The Sage Handbook of Organizational Institutionalism (pp. 311-337). London, UK: Sage.

Ramírez-Alujas, A. V. (2011). Gobierno abierto, servicios públicos 2.0 y ciudadanía digital: notas para una nueva agenda de modernización de la gestión pública en Iberoamérica. Madrid, España: Grupo de Investigación en Gobierno, Administración y Políticas Públicas. Retrieved from https://goo.gl/FP4yR6

São Paulo Aberta. (2016). Relações Internacionais e Federativas. Memória da Iniciativa São Paulo Aberta. São Paulo, SP: Prefeitura de São Paulo.

São Paulo Aberta. (2020). Website. Retrieved from http://www. saopauloaberta.com.br

Scott, R. (2008). Institutions and organizations: ideas and interests. London, UK: Sage.

Selznick, P. (1949). TVA and the grass roots: a study in the sociology of formal organization (v. 43). Berkeley, CA: University of California Press. 
Stren, R., \& Friendly, A. (2017). Mayors in Local Politics: A New Look. In Proceedings of Annual Meeting of the American Political Science Association, San Francisco, CA.

Zucker, L. G. (1977). The role of institutionalism in cultural persistence. American Sociological Review, 42(5), 726-743.

Zucker, L. G. (1987). Institutional theories of organizations. Annual Review of Sociology, 13, 443-464.
Zucker, L. G. (1991). Postscript: Microfoundations of institutional thought. In W. W. Powell, \& P. DiMaggio (Eds.), The new institutionalism in organizational analysis (pp. 103-106). Bingley: Emerald Insight.

Waisbich, L. T. (2018, May 15). Los retos que emergen frente a un proceso electoral: ¿Qué nos enseña el caso de Sao Paulo, Brasil? Open Government Partnership. Retrieved from https://www. opengovpartnership.org/stories/los-retos-que-emergen-frente-aun-proceso-electoral-que-nos-ensena-el-caso-de-sao-paulo-brasil/

Gabriela de Brelàz

ORCID: https://orcid.org/0000-0001-9954-5526

Adjunct Professor at the Federal University of São Paulo (UNIFESP) at the Paulista School of Politics, Economics and Business (EPPEN).

E-mail: gabriela.brelaz@unifesp.brbr

Tamara llinsky Crantschaninov

ORCID: https://orcid.org/0000-0003-4841-9452

Professor at São Paulo School of Sociology and Politics Foundation (FESPSP) by the Graduate Program in Political Science. E-mail: tamaracrants@gmail.com

Laila Bellix

ORCID: https://orcid.org/0000-0003-2345-3558

Co-founder of the Open Government Institute (IGA). E-mail: Ilbellix@gmail.com 